\title{
The importance of determinants influencing FDI inflows within the CEE region ${ }^{3}$
}

Article history:

Received 05 December 2012

Accepted 22 April 2013

Available online 23 April 2013

\begin{abstract}
In this paper, we examine the variables influencing FDI inflows in CEE countries and the sample includes fourteen countries within the CEE region. The variables analyzed in the paper are: financial sector development, human capital and physical infrastructure. Empirical analysis, presented in the paper, indicates that the countries with well-developed capital markets can enhance the level of FDI inflows. Moreover, the same analysis points out a clear link between the total labor force related to a local market and FDI inflows. Finally, the correlation between physical infrastructure development and FDI inflows is set. In the end, creating stable and efficient business environment may influence a higher level of both foreign and domestic investments within the country.
\end{abstract}

Key words: FDI inflows, financial development, human capital, market capitalization, physical infrastructure, labor force.

Apstrakt: U radu se analiziraju varijable koje mogu uticati na priliv SDI u četrnaest zemalja centralne $i$ istočne Evrope. Od pomenutih varijabli ispituje se veza finansijskog sektora, ljudskog kapitala kao i stanja infrastrukture sa prilivom stranog kapitala. Empirijska analiza koja je predstavljena u radu ukazuje na značaj razvoja tržišta kapitala u privlačenju SDI. Takođe, empirijska analiza ukazuje i na jasnu vezu između ljudskog kapitala i priliva SDI. Na kraju, uspostavljena je i korelacija između razvijenosti fizičke infrastrukture i priliva SDI. Upravo stabilno i efikasno poslovno okruženje utiče na nivo stranih investicija u zemlji, a unapređenje istog može pozitivno uticati na dalji priliv većeg broja stranih investicija ali i pospešiti i nivo domaćih.

\footnotetext{
${ }^{1}$ Dr Renata Pindžo, Ministry of Finance and Economy and Faculty of Economics Finance and Administration (FEFA), renata.pindzo@mfp.gov.rs

${ }^{2}$ Ana Vjetrov, MSc, Faculty of Economics, Finance and Administration (FEFA), avjetrov@fefa.edu.rs

${ }^{3}$ This Research Paper was the part of the project "Advancing Serbia's Competitiveness in the Process of EU Accession", no. 47028, in the period 2001-2015, financed by the Serbian Ministry of Science and Technological Development.
} 
Pindžo, Vjetrov: The Importance of Determinants influencing FDI inflows...

Ključne reči: priliv SDI, finansijski sektor, ljudski kapital, tržišna kapitalizacija, fizička infrastruktura, radna snaga

\section{Introduction}

Since the benefits related to foreign direct investments (FDIs) have already been discussed as part of contemporary literature related to that topic, the aim of this paper is to present the determinants influencing FDI inflows within CEE countries. Firstly, the role of the financial system in enhancing FDI inflows in the recipient country will be presented in the paper. Consequently, the link between market capitalization related to companies listed on the stock exchange and FDI inflows, will be shown.

Furthermore, another variable determining FDI inflows will be a focus of this paper. Many authors have pointed out that the labor market is another important determinant influencing FDI inflows. FDIs, being a valuable source of new technology, simultaneously develop the human capital base at the local market. Consequently, host country's level of human capital may determine the level of FDIs and the ability of local companies to absorb the potential spillover benefits as well. Finally, the paper will present the role of physical infrastructure in attracting FDI, as representing an important component of a business environment influencing business activities of both local and foreign enterprises.

Consequently, the following theses are being tested:

$\mathrm{HO}$ :The financial development of the recipient country represents a determinant which is important for the level of FDI inflows.

$\mathrm{H} 1$ :The quality of human capital plays an important role in attracting the considerable amount of FDI inflows.

$\mathrm{H} 2$ :The state of physical infrastructure of the recipient country is positively correlated with FDI inflows.

Finally, this paper will be structured as follows. Section 2 will provide a thorough description of the literature used to determine variables important for attracting FDI. Section 3 will present the data and methodology used in the paper. Section 4 will present FDI trend in 14 countries in Central Eastern Europe (CEE countries) and the results of a comparative analysis. Finally, within section 5 , we will present the empirical results by means of the panel data models. 
Pindžo, Vjetrov: The Importance of Determinants influencing FDI inflows...

\section{Literature review}

The determinants influencing the level of FDIs in the recipient country will be explained in this paper. First of all, the role of the financial system will be presented. Hermes et al. (2003) emphasized the significance of the development of a domestic financial system that represents a necessary condition for the level of FDIs. A crucial assumption in their model is that the domestic financial system influences growth through the level of technology. Moreover, Hermes et al. (2003) emphasized that a stable financial system affects the allocative efficiency related to financial resources over investment projects. Furthermore, authors pointed out that investments related to upgrading existing or adopting new technologies involve greater amount of risk in comparison to other investment projects. Thus, the financial system may reduce this risk by motivating local entrepreneurs to upgrade the existing level of technology. Their empirical studies involve 67 countries, out of which 37 have a relatively developed financial system.

Finally, the results of their empirical studies are interesting. Their conclusions contradict the generally accepted view that an increase in FDI level is positively associated with economic growth of the recipient country. The previous statement is influenced by the development of the domestic financial system. Thus, the final conclusion of the paper is that developing countries should reform their financial system prior to liberalizing the capital account in order to allow large-scale FDI inflows. Furthermore, Alfaro et al. (2004) pointed out that FDI alone have a perplexing role in contributing to the economic growth of the country. Furthermore, their analysis using cross country data in the period 1975-1995 implies that countries with stable and developed financial markets gain significantly from FDI. They indicate that better local conditions are important for both attracting foreign capital and for maximizing its benefits as well.

Additionally, Demirguc et al. (2002) showed the general conclusion that market-based financial system is more dominant in richer countries in comparison to bank-based financial systems. Moreover, Allen et al. (1999) stress out that market based systems have been more effective in encouraging innovation and entrepreneurship. The above mentioned is the main reason for choosing the variable market capitalization of the listed companies as the main indicator for financial development in this paper. Even though this paper analyses the developing countries that are more bank-oriented than market-oriented, the previous researches showed that efficient capital markets attract foreign investors. Consequently, this segment ought to be improved in transitional counties like Serbia ,in order to attract foreign capital. 
Furthermore, this paper examines the relation between FDI and human capital of the host countries. Human capital, that may have an influence on FDI inflows, represents the second determinant in this paper. Van den Berg (2001) argues that the qualifications of labor force, its experience, and the quality of the education system may influence the ability of a country to create new ideas and to modify old ones. Consequently, improvements in education and human capital may be crucial for further technology spillovers, as well as for sustainable long-run growth.

Blomström et al. (2003) state that productivity and technology spillovers are not automatic consequences of FDI. They emphasize that FDI and human capital can be related in a rather complex manner, involving FDI inflows to create a potential for spillovers of knowledge to the labor force. However, this depends both on the capability of the local human capital and on the fact whether local enterprises are capable for absorbing these benefits. The authors state that host economies with high levels of labor force are able to absorb large amounts of technology-driven foreign companies that may play an important role in the further development of human capital within the country. Furthermore, the authors mention that economies with weaker initial human capital bases are prone to attract smaller inflows of FDI and the foreign firms entering local market probably use simpler technologies contributing only partially to learning and skill development of local human capital. However, the author points out that even though there is a large amount of evidence regarding the link between FDI inflows and human capital, further research is essential for acquiring better understanding of this relation.

Finally, the relation between physical infrastructure and FDI inflows will be the focus of this paper as well. In recent studies, Khadaroo et al. (2010) have focused on transport infrastructure and concluded that this kind of infrastructure is positively associated with FDI inflows. Furthermore, the authors point out that the main benefits related to infrastructure improvement are greater accessibility and reduction in transportation costs. Consequently, poor infrastructure leads to bigger transaction costs, thus limiting access to both domestic and foreign markets which ultimately reduces the FDI level in developing countries. Rehman et al. (2010) point out that, in the short run, a one percent increase in infrastructure ends in raising FDI by $1.03 \%$ and, in the long run, a one percent rise in infrastructure uplifts FDI inflows by $1.31 \%$. Finally, the purpose of all studies mentioned above was to investigate the effects of physical infrastructure on FDI inflows in developing countries, which is the case of Serbia as well. 
Pindžo, Vjetrov: The Importance of Determinants influencing FDI inflows...

\section{Methodology}

The data set used in this paper applies to the 2005-2010 period and contains 14 developing countries within the CEE region. The following countries are the focus of our paper: Albania, Bosnia and Herzegovina, Bulgaria, Croatia, Czech Republic, Latvia, Lithuania, Macedonia, Montenegro, Poland, Romania, Serbia, Slovakia and Slovenia. Furthermore, all data used in the analysis are acquired from the World Bank Database, entitled World Development Indicators (WDI). The first variable used in the analysis is foreign direct investment, net inflow, denominated in current U.S. dollars. The variable presents net inflows (new investment inflows less disinvestment) obtained from the World Bank Database.

Furthermore, this paper analyzes the relation between four parameters: financial development, human capital, physical infrastructure and FDI inflows. Financial development of a country is presented by the indicator market capitalization of listed companies in current U.S. dollars. World Bank defines market capitalization as the share price times the number of shares outstanding. Listed domestic companies are the domestically incorporated companies listed on the country's stock exchanges at the end of the year. Human capital is presented using variable labor force total. Additionally, World Bank defines labor force as people belonging to age groups 15 and older who meet the International Labor Organization definition of the economically active population (all people who supply labor for the production of goods and services during a specified period). It includes both the employed and the unemployed. Finally, the development of physical infrastructure is seen through the following variable - roads total network in $\mathrm{km}$. The World Bank defines this variable as total road network including motorways, highways, and main or national roads, secondary or regional roads, and all other roads in a country.

Bearing in mind that our analysis refers to specific number of countries ( $i$ subscript) throughout some period of time ( $t$ subscript) the usage of panel regression imposes itself as a valuable tool. However, it is important to determine which model will be used in the paper: fixed effects model (FE model) or random effects model (RE). Basically, the main difference is in unobservable individual specific effect $\mu_{1}$. If this specific effect $\mu_{1}$ is considered to be a part of a constant, we are dealing with the FE model. Furthermore, this individually specific effect (differs within entities $i$ ) is time invariant and being a part of a constant it may correlate with other regressors. Finally, within this model $\beta$ is consistent, while $\alpha+\mu_{i}$ presents a variable part of the model.

$$
y_{i t}=\left(\alpha+\mu_{i}\right)+X_{i t}^{\prime} \beta+u_{i t} .
$$


Pindžo, Vjetrov: The Importance of Determinants influencing FDI inflows...

Finally, in the FE model OLS (ordinary least squares) and LSDV (least squares dummy variables) are usually used for getting estimates. General model related to RE model is:

$$
y_{i t}=\alpha+X_{i t}^{\prime} \beta+v_{i t} \text { while } v_{i t}=\mu_{i}+u_{i t}
$$

In the RE model the individual effect $(\mu)_{1}$ is considered to be stochastic variable within disturbance. Furthermore, $\mathrm{u}_{\mathrm{it}}$ represents remainder disturbance that varies with entities and times and is considered to be a usual disturbance within equitation. Finally, $\beta$ slope is constant as it is in the RE model. In the RE model GLS and FGLS methods are used for acquiring estimates (depending on whether variance matrix $\Omega$ within groups is familiar or not). In the end, the RE model analyses the group effect over entities and time, assuming the same intercepts and slopes, while individual effects behave as a part of disturbance. Finally, in the RE model $\mu_{\mathrm{i}}$ is not correlated with any explanatory variables.

In the end, we should decide upon the already explained two models. The most frequent tool is the Hausman test where null hypothesis is random effects as the preferred model, while the alternative is the fixed effects model. It basically tests whether individual effects are correlated with the regressors, while the null hypothesis says they are not. If Prob>chi2 is less than 0.05, than we should use fixed effects model. Additionally, $F$ test is used to test acquired coefficients in the FE model, while Lagrange multiplier is used in the RE model. The statistical program applied for acquiring results in the paper is STATA.

\section{Comparative analysis - FDI trends in CEEcountries}

Before presenting the results of our analysis we will present the volume and the structure of FDI in Serbia and compare it with the regional countries. According to Business Info Group (2012) and its document 'Foreign Direct Investments in Serbia 2001-2012', the entire period can be divided into three sub-periods: 2001-2005, 2006-2008 and 2009-2011. During the first period, FDI in Serbia reached a level of approximately EUR 3.1 billion. Furthermore, the largest portion of this amount was invested in privatization of companies (tobacco industries, breweries, some food processing and metal processing industrial groups). The same document indicates the second period of FDI in Serbia, when FDI amounted to EUR 6.3 billion, when the greatest volume of FDI was accomplished during 2006 (EUR 3.3 billion), when the largest transaction was made (through the sale of a mobile operator Mobtel to the Norwegian giant Telenor for EUR 1.5 billion). Finally, in the last period, FDI reached a total of EUR 4.2 billion, while the biggest single FDI during 2011 was the sale of Serbia's biggest retail chain, Delta-Maxi, to the Belgian Chain Deleuze 
Pindžo, Vjetrov: The Importance of Determinants influencing FDI inflows...

for EUR 933 million. The Table 1 presents Net Foreign Direct Investments during the period 2001-2011.

Table 1 - Net Foreign Investments in Serbia 2001-2011 in EUR mil.

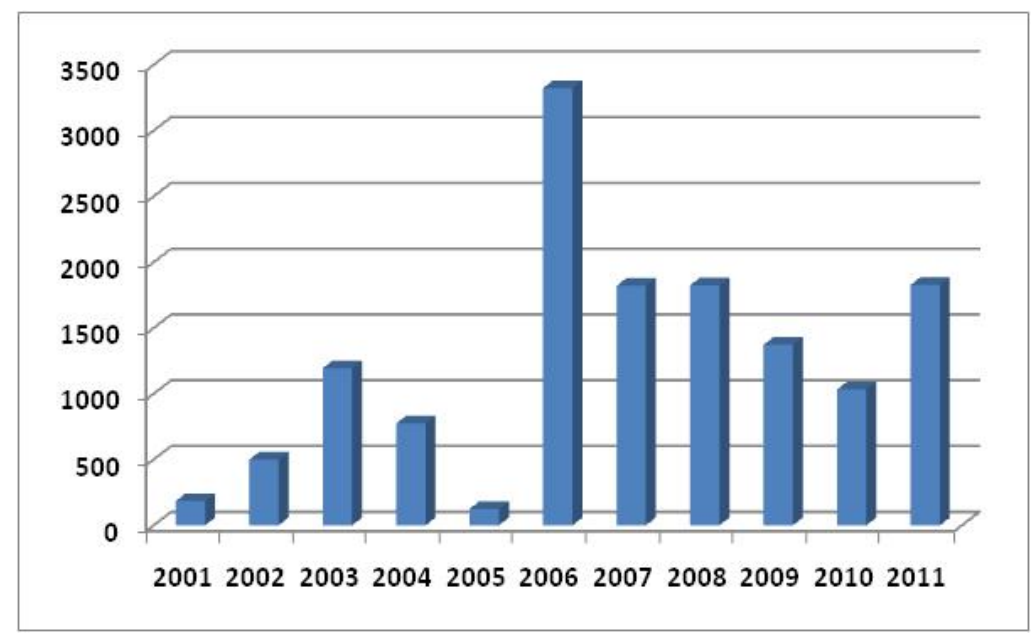

Source: Business Info Group (2012), Foreign Direct Investments in Serbia 2001-2011, Beograd

Furthermore, Business Info Group (2012) states that total investments in Serbia in the period 2001-2011 recorded a real growth at an average annual rate of about $6 \%$ and that the volume of investments decreased by about $20 \%$ in the period of economic crisis (2009-2011), compared to the previous three years. If the structure of FDI is being analyzed, the largest portion of FDI was invested in financial services $(27.9 \%)$, in manufacturing industry $(19.9 \%)$, wholesale and retail trade $(16.2 \%)$, retail $(13.8 \%)$, postal services and telecommunications (11.8\%) and other $8.1 \%$.

If the national origin of the companies is analyzed, the dominance of EU countries as well as of the American and Russian companies is obvious. The following is presented in the Table 2.

Document Doing Business in Serbia (SIEPA, 2012) published by SIEPA (Serbia Investment and Export Promotion Agency) states that Russian investments dominate the oil and gas sector (Gazprom and Lukoil). Norway with Telenor dominates within telecommunication sector regarding the value of FDI, while Belgium's contribution to overall FDI stock is visible through the acquisition of the local food retailer Maxi. Furthermore, Greek banks were among the first to enter the Serbian market between 2001 and 2006. Austria tops the list primarily due to the closeness of the two economies, while Ger- 
Pindžo, Vjetrov: The Importance of Determinants influencing FDI inflows...

many and Italy are Serbia's main foreign trade partners and key contributors to FDI. The Table results show that Germany, Italy and Slovenia are very important for Serbia in terms of projects and investment value.

Table 2 - FDI ranking by number of projects and by value in Serbia within 2001-2011

\begin{tabular}{|l|l|l|l|l|l|l|l|l|l|}
\hline \multirow{3}{*}{$\begin{array}{l}\text { FDI RANKING BY N0. OF } \\
\text { PROJECTS }\end{array}$} & $15.50 \%$ & $13.5 \%$ & $13.2 \%$ & $10.6 \%$ & $5.9 \%$ & $5.6 \%$ & $5.0 \%$ & $3.3 \%$ & $3.0 \%$ \\
\hline & Germany & Italy & Austria & Slovenia & Greece & France & Israel & US & Croatia \\
\hline \multirow{3}{*}{ FDI RANKING BY VALUE } & $12.90 \%$ & $11.10 \%$ & $10.20 \%$ & $8.20 \%$ & $7.70 \%$ & $7.20 \%$ & $5.90 \%$ & $5.10 \%$ & $5.10 \%$ \\
\cline { 2 - 10 } & Austria & Italy & Greece & Norway & Germany & US & Slovenia & Russia & Belgium \\
\hline
\end{tabular}

Source: SIEPA (2012), Doing Business in Serbia, Belgrade

Furthermore, after analyzing the volume and structure of FDI in Serbia, it is important to stress out why investors should invest in Serbia. SIEPA (2012) emphasizes a favorable geographic position. The same document focuses on the low operating costs. It points out that Serbia's tax regime is highly beneficial for doing business. Moreover, utility costs are among the lowest in Europe. The prices of electricity, gas and other fuels, postal services, landline telephony, fax services, are the lowest among 37 European countries.

Nevertheless, we should also mention the financial incentives granted to foreign investors. The said documents emphasize that the total number of subsidized projects is 226, with the total value of EUR 1.29 million. The number of created jobs amounted to 40,088 . Special packages are available to large investors who invest at least EUR 50 million and employ 300 people, and to medium-sized investors who employ 150 people and invest at least EUR 50 million. These projects are eligible to receive up to $20 \%$ or $10 \%$ of the total investment value, respectively. Finally, the level of FDI net inflows between Serbia and the regional countries is presented in Table 3.

The Table 3 shows the latest trend in FDI net inflow in transitional countries within the period 2005-2011. Furthermore, the data show that Poland, Croatia, Czech Republic, Slovakia and Serbia represent the countries with the highest level of net inflows within the region. The results also show that Poland experienced significant increase in FDI after its accession to the EU in 2004. Furthermore, Poland accomplished 121 FDI projects in 2011, ranking it second in CEE (Ernst\&Young 2012). The country is strong in the production of automotive components and vehicle assembly. During 2011, companies including Volkswagen AG and Bridgestone Corporation invested in Poland's automotive sector (Ernst\&Young 2012). 
Pindžo, Vjetrov: The Importance of Determinants influencing FDI inflows...

Table 3 - Net Foreign Investments within CEE countries in U.S.D. mn,.20052011

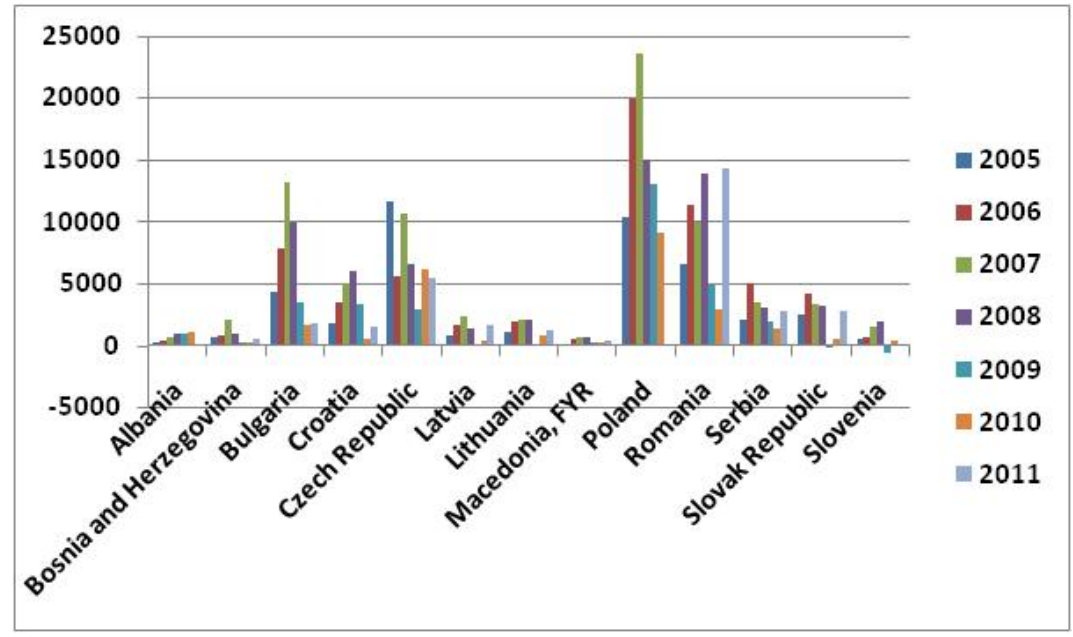

Source: World Bank Database, World Bank Indicators, http://databank. worldbank.org/ddp/home.do?Step $=1 \& i d=4$

However, the devastating influence of the financial crisis is quite apparent, reducing the overall level of $\mathrm{FDI}$ in most countries. However, a country like Slovenia is the example of an economy as, in most cases, a home country for FDI rather than a host country. When we compare Serbia with other Balkan countries, it is clear that Serbia has accomplished better results concerning the overall value of FDIs in the last three years. For example, Business Info Group (2012) states that during 2011 FDls amounted to EUR 1.82 billion in Serbia, EUR 1.2 billion in Croatia, EUR 1.06 billion in Bulgaria, EUR 650 million in Albania, etc. After analyzing the volume and structure of FDIs in Serbia and presenting the results of the comparative analysis between the countries in the region, the following chapter presents the results of our analysis with regard to the relation between financial development, human capital and FDI inflows.

\section{Empirical results}

The hypotheses will be tested in the following paragraph. The main hypothesis (HO) examines the financial system as a determinant having a significant role in attracting FDls. It refers to the fact that the strengthening of the local financial system leads to the increase in FDI inflows. As already presented in the section on methodology, the development of a financial system can be seen through the variable market capitalization of listed companies. Thus, in 
Pindžo, Vjetrov: The Importance of Determinants influencing FDI inflows...

the following chapter, a possible link between market capitalization of listed companies and FDI net inflows will be explained using the panel data analysis. Furthermore, the link between variables labor force total and FDI net inflows will be the object of panel data analysis as well. In the end, the relation between physical infrastructure and FDI inflows will be examined in the paper. Nevertheless, market capitalization, total labor force, total roads network in $\mathrm{km}$ are used as predictors in regression analysis, while variable FDI inflows are used as a response.

The Hausman test within STATA is done with the aim of choosing between the RE and FE effects model. Within the Hausman test, the null hypothesis states that the preferred model is random effects while alternative hypothesis implies the usage of fixed effects. If Prob>chi2 is less than 0.05 (i.e. significant), in the further analysis of variables the FE model should be used. The results acquired from STATA show that Prob $>$ chi $2=0.006$, i.e. is less than 0.05 . The results imply the rejection of the null hypothesis. Consequently, the Hausman test indicates the use of the FE model in our further analysis. Thus, the results of the FE model are presented comparing the following variables: market capitalization and total labor force representing the independent variables and finally FDI net inflows representing the dependent variable. The latter examines the link between variable FDI inflows and both financial and human capital development.

Moreover, statistical significance of the regression model depends on $p$-value. According to the final data acquired from STATA, all $p$ values related to the variables total labor force and market capitalization are less than $0.05(0.012$ and 0.029 respectively), indicating that we are dealing with a statistically significant regression model, where at least one of the independent variables has significant influence on the dependant variable.

Furthermore, coefficients related to independent variables indicate the relation between $X$ and $Y$ in regression: how $Y$ (dependent variable) changes when $X$ (independent) variable increases by one unit, providing that all the other independent variables are constant. The results show that FDI net inflows will decrease by 7,792 when variable total labor force goes up by one (presented on Table 4 in the text). This may be interpreted in a way which illustrates that the increase related to total labor force is influenced by the increase related to the unemployment rate (it has already been explained that if follow the WB definition the total labor force includes both the employed and the unemployed). In that case the regression results may indicate that macroeconomic instability embodied in the unemployment increase may prevent the foreigners from further investing. The results show that the level of human capital influences the level of FDI inflows. 
Pindžo, Vjetrov: The Importance of Determinants influencing FDI inflows...

There is a negative correlation coefficient calculated in STATA among these two variables. The coefficient is -0.4 , indicating that the decrease in unemployment is followed by an increase in FDI net inflows. Furthermore, the results on the Table 4 in the text also show that an increase related to variable market capitalization by one unit is followed by increase in FDI net inflows by 0.05 . The latter shows that the financial system development is a necessary precondition for attracting FDI. Furthermore, a positive correlation coefficient 0.6 calculated in STATA among these two variables shows that an increase in FDI net inflows is followed by an increase in market capitalization.

Table 4 - Results of FE model for the period 2005-2010 related to fourteen CEE countries

\begin{tabular}{|l|c|c|c|c|}
\hline \multicolumn{5}{|c|}{ FDI inflows dependent variable } \\
\hline $\begin{array}{l}\text { independent varia- } \\
\text { bles }\end{array}$ & Coef. & Std.Err. & T & P \\
\hline laborforcetotal & -7792.414 & 2997.714 & -2.60 & 0.012 \\
\hline Market capitalization & .047 & 0.021 & 2.25 & 0.029 \\
\hline Fixed effect (country) & Yes & & & \\
\hline R-sq (within) & 0.1639 & & & \\
\hline R-sq (between) & 0.7800 & & & \\
\hline R-sq (overall) & 0.4812 & & & \\
\hline F-test & 5.00 & & F-test $\left(\mu_{\mathrm{i}}\right)$ & 3.38 \\
\hline p-value & 0.01 & & p-value $\left(\mu_{\mathrm{i}}\right)$ & 0.00 \\
\hline Corr $\left(\mu_{\mathrm{i}}, \mathrm{X}_{\mathrm{it}}\right)$ & -0.99 & & & \\
\hline
\end{tabular}

Source: World Bank Database, World Bank Indicators, retrieved from http://databank. worldbank.org/ddp/home.do?Step=1\&id=4

The value of R-Squared has to be scrutinized thoroughly. The R-squared of the regression presents the level of variability of the dependent variable that is determined by the independent one. Furthermore, the R-squared presented within the results of the FE model has the following values: R-sq within equals 0.17 , R-sq between equals 0.78 and finally $R$-sq overall equals 0.48 . Consequently, if $\mathrm{R}$-sq between is taken into consideration, the independent ones determine 78 percent of variability related to the dependant variable. Moreover, number of observations in the panel data analysis reaches 64 . In the end, an $\mathrm{F}$ test in our example (Prob $>\mathrm{F}=0.01$ ) tests whether all the coefficients in the model are different from zero, providing this value is less than 0.05 . Considering the fact that acquired 0.01 is less than 0.05 , our model is acceptable.

Finally, Table 5 in the text, clearly points out a strong positive correlation between variables roads total network in km and FDI inflows. Pearson correla- 
Pindžo, Vjetrov: The Importance of Determinants influencing FDI inflows...

tion coefficient reaches 0.8 and is statistically significant. Moreover, the results of correlation coefficients for all the variables presented in the paper are given on the following table:

Table 5 - Correlation calculated from 2005 till 2010 for CEE region

\begin{tabular}{|l|c|c|}
\hline FDI inflows & $\begin{array}{c}\text { Pearson corre- } \\
\text { lation coeffi- } \\
\text { cient }\end{array}$ & P value \\
\hline Market capitalization & 0.6 & 0.00 \\
\hline Labor force total & 0.71 & 0.00 \\
\hline Telephone lines & 0.71 & 0.00 \\
\hline Internet users & 0.59 & 0.00 \\
\hline Roads total km & 0.78 & 0.00 \\
\hline
\end{tabular}

Source: World Bank Database, World Bank Indicators, retrieved from http://databank.worldbank.org/ddp/home.do?Step $=1 \& \mathrm{id}=4$

In the end, the results obtained from the panel data analysis are statistically significant and there is a higher value of $\mathrm{R} \mathrm{sq}$ as well. The latter reveals the fact that the link between variables labor force and market capitalization and FDI inflow may be set. The results confirm the two hypotheses referring to the fact that stable and efficient domestic financial system and human capital are important determinants for further FDI attracting in the countries within the CEE region. The empirical results confirm the previous cross-country analysis implying that countries with well-developed financial markets can significantly take advantage of foreign capital. Furthermore, the previous analysis indicates that better local conditions contribute to the maximization of the benefits related to foreign investments. Our results show that the increase in market capitalization is followed by the increase in FDI inflows, thus confirming the necessity for improving capital markets efficiency for countries like Serbia. Market-based systems are shown to provide better cross-sectional risk sharing and to create stronger financial innovation incentives (Ayyagari et al., 2012). Consequently, the development of capital markets may have various implications - FDI attracting, level of innovation increase as well as risk reducing while financing various activities of companies, considering the fact that the risk is divided among a large number of investors buying companies' shares. Finally, the link between the level of human capital and FDI inflows is set. However, the results show negative relation among FDI inflows and the total labor force. The latter may indicate that the reduction in unemployment rate may be a step forward in relation to macroeconomic stability which presents a necessary precondition for attracting foreign capital. Finally, infrastructure development is important for FDI attracting, but it is not enough. The success in FDI enhancing is inseparable from the improvement of the financial infrastructure of the country. 
Pindžo, Vjetrov: The Importance of Determinants influencing FDI inflows...

\section{Conclusion}

The main focus of this paper is to determine the variables influencing the level of FDls within a country. The analysis is done on the sample including 14 countries from the CEE region. Furthermore, this paper analyzes the relation between the following parameters: financial development, human capital, physical infrastructure and FDI inflows. Financial development of the country is presented by the indicator market capitalization of listed companies in current U.S. dollars. Additionally, human capital is presented using variable labor force total. Physical infrastructure development is described by variable total roads network in $\mathrm{km}$. The last variable in the analysis is FDI inflows. It is important to stress out that all indicators were obtained from the World Bank Data Base.

The paper sets three hypotheses. The first one states that the financial development of a country influences the increase of the FDI inflows. Furthermore, the second hypothesis stresses out that the level of human capital influences FDI inflows within CEE countries. The last hypothesis emphasizes the importance of physical infrastructure for further FDI attracting. In order to confirm those hypotheses the authors have used panel data analysis. The panel data analysis implies the use of two models - the FE model and the RE model. By means of the Hausmann test within the statistical software STATA the authors have chosen the FE model for their analysis. This models uses market capitalization of listed companies' total labor force and total roads network in $\mathrm{km}$ as predictors, while $F D I$ inflows is taken as a response in regression analysis.

Consequently, the final results confirmed those hypotheses. Considering the fact that the results are statistically significant and that there is a high value of $\mathrm{R}$ sq as well, the link between labor force and market capitalization and FDI inflows may be set. Furthermore, a positive strong correlation between total roads network and FDI inflows is established. The result confirm the hypotheses that refer to the fact that the development of a domestic financial system is an important precondition for FDI captivating and that FDI inflows are influenced by the level of labor force within the country. If Serbia is taken into consideration, the conclusions are twofold. First, capital markets have to be more efficient and more frequently used for corporate and investment financing in order to attract the level of FDI. In the end, the high unemployment rate, amounting to $24 \%$ at the end of 2011 , has to be reduced in order to secure macroeconomic stability for further FDI captivating. The same results apply to the whole CEE region indicating the importance of both financial development and human capital for foreign capital inflows. However, the results indicate that the development of physical infrastructure is a good precondition for FDI inflows, but that it presents only initial step in the whole process. The final 
Pindžo, Vjetrov: The Importance of Determinants influencing FDI inflows...

progress in FDI attracting is influenced by the financial infrastructure of a country.

\section{References}

Allen, F., \& Gale, D. (1999). Diversity of opinion and financing of new technologies. European Economic Review, 39, 179-209.

Alfaro, L., Chanda, A., Kalemli-Ozcan, S., \& Sayek, S. (2004). FDI and economic growth: the role of local financial markets. Journal of International Economics, 64(1), 89-112. doi:10.1016/S0022-1996(03)00081-3

Ayyagari, M., Demirguc-Kunt, A., \& Maksimovic, V. (2012). Financing of firms in developing countries. The World Bank, Financial and Private Sector Development. April.

-Business Info Group. (2012). Foreign Direct Investments in Serbia 2001-2011. Beograd.

Blomstr, (., \& Kokko, A. (2003). Human Capital and Inward FDI, The European Institute of Japanese Studies. The European Institute of Japanese Studies. Working Paper no. 167.

Demirgüç-Kunt, A., \& Maksimovic, V. (2002). Funding growth in bank-based and market-based financial systems: evidence from firm-level data. Journal of Financial Economics, 65(3), 337-363. doi:10.1016/S0304-405X(02)00145-9

-Ernst \& Young. (2012). 2012 European attractiveness survey. Retrieved from http://www.ey.com/Publication/vwLUAssets/Attractiveness 2012 europe/\$FILE/ Attractiveness 2012 europe.pdf

Hermes, N., \& Lensink, R. (2003). Foreign Direct Investment, Financial Development and Economic Growth. Journal of Development Studies, 142-163.

Khadaroo, A.J., \& Seetanah, B. (2010). Transport Infrastructure and FDI. Journal of International Development, 22, 103-123.

Rehman, A., Ilyas, M., Alam, H., \& Akram, M. (2011). The Impact of Infrastructure on Foreign Direct Investment: The case of Pakistan. International Journal of Business and Management, 6(5),

-SIEPA. (2012). Doing Business in Serbia. Belgrade.

van den Berg, H. (2001). Economic Growth and Development. Singapore: McGrawHill.

World Bank Database. World Bank Indicators, Retrieved from http://databank. worldbank.org/ddp/home.do?Step=1\&id=4 